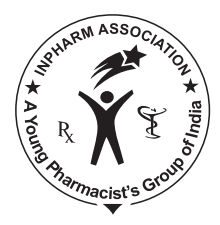

\title{
JVP
}

\section{Antitumor, Analgesic, and Anti-inflammatory Activities of Synthesized Pyrazolines}

\author{
Jainey PJ, Bhat IK \\ Department of Pharmaceutical Chemistry, NGSM Institute of Pharmaceutical Sciences of Nitte University, \\ Deralakatte, Mangalore, Karnataka, India
}

Address for correspondence: Ms. Jainey P James; E-mail: jaineyjames@ gmail.com

\begin{abstract}
Nitrogen heterocyclic compounds such as pyrazolines have been found to possess a broad spectrum of biological activities such as anticancer, antitubercular, anti-inflammatory, analgesic, and antidepressant activities. Pyrazoline derivatives IV, V (a-e) have been synthesized from the intermediate chalcones III $(a-h)$ by cyclizing with phenyl hydrazine and hydrazine hydrate. The structures of these compounds were confirmed by IR, NMR, and mass spectroscopy. Biological studies of the synthesized compounds showed promising antitumor, analgesic, and anti-inflammatory activities. The compounds were tested for their in vitro antitumor activity against EAC tumor cell lines. Compounds IVa and IVb showed the highest cytotoxicity of $80 \%$ at a $200 \mu \mathrm{g} / \mathrm{mL}$ concentration. Among the tested compounds, IVa and Vd seem to be more effective analgesic agents. Compounds IVc, IVd, and Ve are found to be the most effective anti-inflammatory agents. Thus the results show that synthesized compounds possess antitumor, analgesic, and anti-inflammatory activity. It was observed that the test compounds with electron withdrawing groups (halogens) on the aromatic ring favors antitumor, analgesic, and anti-inflammatory activity.
\end{abstract}

Key words: Analgesic, anti-inflammatory activity, antitumor, chalcones, pyrazolines

\section{INTRODUCTION}

Recently, different authors worldwide have reported antitumor, antiproliferative, or anticancer potential of thiophene, ${ }^{[1]}$ and pyrazoline derivatives. ${ }^{[2]}$ This gave us immense confidence to carry out work on pyrazoline which possesses antitubercular, ${ }^{[3]}$ antidepressant, ${ }^{[4]}$ anticonvulsant, ${ }^{[4]}$

\begin{tabular}{|l|l|}
\hline \multicolumn{2}{|c|}{ Access this article online } \\
\hline Quick Response Code: & \\
\hline & Website: \\
\hline & www.jyoungpharm.in \\
& DOI: \\
\hline
\end{tabular}

antitumor, ${ }^{[5]}$ anti-inflammatory, ${ }^{[6]}$ analgesic, ${ }^{[6]}$ and anticancer ${ }^{[7]}$ activities. Pain directly related to cancer or caused by treatments for cancer is a highly prevalent clinical problem. Therefore, analgesics and anti-inflammatory drugs are prescribed simultaneously along with cancer chemotherapeutics, in normal practice. Due to great potential of both the moieties, synthesis of pyrazoline bearing thiophene [IVa-d, $\mathrm{Va}-\mathrm{d}]$ was carried out to evaluate antitumor, anti-inflammatory, and analgesic potential.

Pyrazolines are synthesized from the intermediate chalcones by the condensation of 2-acetyl thiophene with substituted benzaldehydes. Chalcones are of great interest as compounds exhibiting antimalarial, ${ }^{[8]}$ anticancer, ${ }^{[0]}$ antioxidant, ${ }^{[9]}$ analgesic, ${ }^{[10]}$ and anti-inflammatory ${ }^{[10]}$ activities. 
The drug development program has employed testing in a few well characterized transplantable animal tumor systems. Simple in vitro assays shorten the testing program. Here the method is tryphan blue exclusion and the tumor cell lines are Ehrlich Ascites Carcinoma (EAC). ${ }^{[1]}$

\section{MATERIALS AND METHODS}

Melting points were determined by the capillary method and were uncorrected. The IR spectra are recorded by using a Shimadzu Perkin Ekmer 8201 PC IR Spectrometer and using a thin film on potassium bromide pellets techniques and frequencies are expressed in $\mathrm{cm}^{-1}$. The PMR spectra were recorded on a Bruker Avance II 400 NMR spectrometer. All spectra were obtained in $\mathrm{CDCl}_{3}$ and Dimethyl sulphoxide (DMSO). Chemical shift values are reported as values in ppm relative to TMS $(\delta=0)$ as an internal standard. The FAB mass spectra were recorded on a JEOL SX-102/DA-6000 Mass spectrometer using Argon/Xenon (6 kV, $10 \mathrm{Ma}$ ) as the FAB gas. All the animal experiments were approved by institutional animal ethical committee (IAEC).

\section{General procedure for synthesis of chalcones}

A mixture of 2-acetyl thiophene $(0.01 \mathrm{~mol})$ and substituted benzaldehydes $(0.01 \mathrm{~mol})$ in ethanol $(20 \mathrm{ml})$ were stirred together for $24 \mathrm{~h}$, in the presence of $20 \% \mathrm{NaOH}(4 \mathrm{ml})$. The mixture was poured into crushed ice and acidified with $5 \% \mathrm{HCl}$. The product (substituted chalcones) obtained was filtered, washed with water, and re-crystallized from suitable solvents [Table 1].

3-(4-Fluorophenyl)-1-(thiophen-2-yl) prop-2-en-1-one

IR $\left(\mathrm{KBr}, \mathrm{cm}^{-1}\right): 1648.9(\mathrm{CO}), 1596.4$ (aliphatic $\mathrm{C}=\mathrm{C}$ ), 3067.7 $(\mathrm{C}-\mathrm{H}), 1516$ (aromatic $\mathrm{C}=\mathrm{C}), 1216.2(\mathrm{C}-\mathrm{F}) ;{ }^{1} \mathrm{H}$ NMR ( $\delta \mathrm{ppm}): 7.79(\mathrm{~d}, 1 \mathrm{H},=\mathrm{CH}), 7.18(\mathrm{~d}, 1 \mathrm{H},=\mathrm{CH}), 7.52-7.87$ (m, 7H, Ar-H); Mass (m/z): 232.

\section{3-(4-Chlorophenyl)-1-(thiophen-2-yl)prop-2-en-1-one}

Table 1: Physical data of substituted chalcone derivatives

\begin{tabular}{lclcc}
\hline Chalcones & $\mathbf{R}$ & Molecular formula & MP $\left({ }^{\circ} \mathbf{C}\right)$ & \% Yield \\
\hline $\mathrm{IV}$ & $4-\mathrm{Cl}$ & $\mathrm{C}_{13} \mathrm{H}_{9} \mathrm{ClOS}$ & $80-82$ & 78 \\
$\mathrm{IVb}$ & $4-\mathrm{F}$ & $\mathrm{C}_{13} \mathrm{H}_{9} \mathrm{FOS}$ & $83-85$ & 75 \\
$\mathrm{IVc}$ & $4-\mathrm{OH}$ & $\mathrm{C}_{13} \mathrm{H}_{10} \mathrm{O}_{2} \mathrm{~S}$ & $104-106$ & 62 \\
$\mathrm{IVd}$ & $4-\mathrm{N}\left(\mathrm{CH}_{3}\right)_{2}$ & $\mathrm{C}_{15} \mathrm{H}_{15} \mathrm{NOS}$ & $87-89$ & 68 \\
$\mathrm{Va}$ & $4-\mathrm{CH}_{3}$ & $\mathrm{C}_{14} \mathrm{H}_{12} \mathrm{OS}$ & $96-98$ & 77 \\
$\mathrm{Vb}$ & $3-\mathrm{OH}$ & $\mathrm{C}_{13} \mathrm{H}_{10} \mathrm{O}_{2} \mathrm{~S}$ & $88-90$ & 68 \\
$\mathrm{Vc}$ & $3-\mathrm{Cl}$ & $\mathrm{C}_{13} \mathrm{H}_{9} \mathrm{ClOS}$ & $92-95$ & 63 \\
$\mathrm{Vd}$ & $3-\mathrm{NO}_{2}$ & $\mathrm{C}_{13} \mathrm{H}_{9} \mathrm{NO}_{3} \mathrm{~S}$ & $111-112$ & 68 \\
\hline
\end{tabular}

IR $\left(\mathrm{KBr} \mathrm{cm}^{-1}\right)$ : $1672.8(\mathrm{CO})$ group, 1611.3 (aliphatic $\left.\mathrm{C}=\mathrm{C}\right)$, $2924.1(\mathrm{C}-\mathrm{H}), 1533.7$ (aromatic $\mathrm{C}=\mathrm{C}), 765.3(\mathrm{C}-\mathrm{Cl}$ ); ${ }^{1} \mathrm{H}$ NMR $(\delta \mathrm{ppm}): 6.97-6.99(\mathrm{~d}, 1 \mathrm{H},=\mathrm{CH}), 6.71-6.72$ $(\mathrm{d}, 1 \mathrm{H},=\mathrm{CH}), 7.53-7.89(\mathrm{~m}, 7 \mathrm{H}, \mathrm{Ar}-\mathrm{H})$; Mass (m/z): 248.

3-(4-Methylphenyl)-1-(thiophen-2-yl) prop-2-en-1-one IR $\left(\mathrm{KBr} \mathrm{cm}^{-1}\right)$ : 1683.5 (CO), 1609.7 (aliphatic $\mathrm{C}=\mathrm{C}$ ), 2987.3 $(\mathrm{C}-\mathrm{H}), 1523.5$ (aromatic $\mathrm{C}=\mathrm{C}), 765.3(\mathrm{C}-\mathrm{Cl}) ;{ }^{1} \mathrm{H}$ NMR ( $\delta$ ppm): 7.12-7.14 (d, $1 \mathrm{H},=\mathrm{CH}), 7.17-7.19(\mathrm{~d}, 1 \mathrm{H},=\mathrm{CH})$, 7.51-7.899 (m, 7H, Ar-H); Mass (m/z): 228.

\section{General procedure for synthesis of pyrazolines}

A mixture of substituted chalcones $(0.01 \mathrm{~mol})$ in $20 \mathrm{ml}$ of ethanol and phenyl hydrazine, hydrazine hydrate $(0.01 \mathrm{~mol})$ were added and refluxed for $5-8 \mathrm{~h}$ and 16-20 h, respectively, in the presence of few drops of pyridine as catalyst. After the completion of the reaction, the reaction mixture was poured into $250 \mathrm{ml}$ of ice cold water. The solid separated is filtered and washed with cold water. The separated compound is recrystallized by using methanol/ethyl acetate. Ethyl acetate: acetone (9:1) is the solvent system for TLC [Table 2].

5-(4-Fluorophenyl)-1-phenyl-3-(thiophen-2-yl)-4,5-dibydro-1Hpyrazole

IR $\left(\mathrm{KBr} \mathrm{cm}^{-1}\right)$ : $3431(\mathrm{C}-\mathrm{H}), 1646.8(\mathrm{C}=\mathrm{N}), 1324.3$ $(\mathrm{C}-\mathrm{N}), 1594.7(\mathrm{C}=\mathrm{C}), 1224.9(\mathrm{C}-\mathrm{F}) ;{ }^{1} \mathrm{H}$ NMR $(\delta \mathrm{ppm})$ : 3.064-3.124 (dd, 1H, Ha), 3.786-3.859 (dd, 1H, Hb), 5.213-5.261 (dd, 1H, Hc), 6.76-7.31 (m, 12H, Ar-H); Mass (m/z): 322 .

5-(4-Chlorophenyl)-1-phenyl-3-(thiophen-2-yl)-4, 5-dibydro-1Hpyrazole

IR $\left(\mathrm{KBr} \mathrm{cm}^{-1}\right): 3039.6(\mathrm{C}-\mathrm{H}), 1635.6(\mathrm{C}=\mathrm{N}), 1336.7(\mathrm{C}-\mathrm{N})$, $1522.5(\mathrm{C}=\mathrm{C}), 703.8(\mathrm{C}-\mathrm{Cl}) ;{ }^{1} \mathrm{H}$ NMR $(8 \mathrm{ppm}): 3.049-3.109$ (dd, 1H, Ha), 3.779-3.852 (dd, 1H, Hb), 5.190-5.239 (dd, $1 \mathrm{H}, \mathrm{Hc}), 6.769-7.308$ (m, 12H, Ar-H); Mass (m/z): $\left(\mathrm{M}^{+}\right)$ 338, $\left(\mathrm{M}^{+}+2\right) 340$.

5-(4-Fluorophenyl)-3-(thiophen-2-yl)-4,5-dibydro-1H-pyrazole IR $\left(\mathrm{KBr} \mathrm{cm}^{-1}\right): 3239.2(\mathrm{C}-\mathrm{H}), 1546.3(\mathrm{C}=\mathrm{N}), 1499.33$

Table 2: Physical data of the synthesized pyrazolines

\begin{tabular}{lclcc}
\hline Pyrazolines & $\mathbf{R}$ & Molecular formula & MP $\left({ }^{\circ} \mathrm{C}\right)$ & \% Yield \\
\hline $\mathrm{IV}$ & $4-\mathrm{Cl}$ & $\mathrm{C}_{19} \mathrm{H}_{15} \mathrm{ClN}_{2} \mathrm{~S}$ & $153-155$ & 69 \\
$\mathrm{IVb}$ & $4-\mathrm{F}$ & $\mathrm{C}_{19} \mathrm{H}_{15} \mathrm{FN}_{2} \mathrm{~S}$ & $158-160$ & 71 \\
$\mathrm{IVc}$ & $4-\mathrm{CH}_{3}$ & $\mathrm{C}_{20} \mathrm{H}_{18} \mathrm{~N}_{2} \mathrm{~S}$ & $106-108$ & 55 \\
$\mathrm{IVd}$ & $3-\mathrm{NO}_{2}$ & $\mathrm{C}_{19} \mathrm{H}_{15} \mathrm{~N}_{3} \mathrm{O}_{2} \mathrm{~S}$ & $175-177$ & 49 \\
$\mathrm{Va}$ & $\mathrm{p}-\mathrm{Cl}$ & $\mathrm{C}_{13} \mathrm{H}_{11} \mathrm{ClN}_{2} \mathrm{~S}$ & $171-174$ & 68 \\
$\mathrm{Vb}$ & $p-\mathrm{F}$ & $\mathrm{C}_{13} \mathrm{H}_{11} \mathrm{FN}_{2} \mathrm{~S}$ & $159-161$ & 65 \\
$\mathrm{Vc}$ & $p-\mathrm{CH}_{3}$ & $\mathrm{C}_{14} \mathrm{H}_{14} \mathrm{~N}_{2} \mathrm{~S}$ & $88-90$ & 43 \\
$\mathrm{Vd}$ & $m-\mathrm{NO}_{2}$ & $\mathrm{C}_{13} \mathrm{H}_{11} \mathrm{~N}_{3} \mathrm{O}_{2} \mathrm{~S}$ & $145-147$ & 51 \\
\hline
\end{tabular}


$(\mathrm{C}-\mathrm{N}), 1523.9(\mathrm{C}=\mathrm{C}), 1197.3(\mathrm{C}-\mathrm{F}) ;{ }^{1} \mathrm{H}$ NMR $(\delta \mathrm{ppm})$ : 3.064-3.124 (dd, 1H, Ha), 3.786-3.859 (dd, 1H, Hb), 5.213-5.261 (dd, 1H, Hc), 6.76-7.31 (m, 12H, Ar-H); Mass (m/z): 246.

5-(4-Chlorophenyl)-3-(thiophen-2-yl)-4,5-dibydro-1H-pyrazole IR $\left(\mathrm{KBr} \mathrm{cm}^{-1}\right)$ : $3141.1(\mathrm{C}-\mathrm{H}), 1689.6(\mathrm{C}=\mathrm{N}), 1421.3(\mathrm{C}-\mathrm{N})$, $1583.9(\mathrm{C}=\mathrm{C}), 737.2(\mathrm{C}-\mathrm{Cl}) ;{ }^{1} \mathrm{H}$ NMR $(\delta \mathrm{ppm}): 3.106-3.198$ (dd, 1H, Ha), 3.657-3.748 (dd, 1H, Hb), 5.891-5.931 (dd, 1H, Hc), 6.331-7.05 (m, 12H, Ar-H); Mass (m/z): $\left(\mathrm{M}^{+}\right)$ 262, $\left(\mathrm{M}^{+}+2\right) 264$.

\section{Antitumor activity}

The synthesized compounds were tested for their cytotoxicity in vitro, in comparison with 5-fluorouracil as a reference drug, against EAC cells. EAC cells $\left(1 \times 10^{6}\right)$ were incubated with synthesized compounds at various concentrations of $25,50,100$, and $200 \mu \mathrm{g} / \mathrm{ml}$, in $1 \mathrm{ml}$ phosphate buffered saline (incorporated with $10 \mu \mathrm{L}$ DMSO) at $37^{\circ} \mathrm{C}$ for $3 \mathrm{~h}$. Viable cells were counted in a hemocytometer using the tryphan blue dye exclusion method. ${ }^{[12]}$ Experiments were carried out in triplicate, and results are reported in Table 3.

\section{Pharmacological screening}

\section{Animals}

Adult female albino rats were used for acute toxicity studies. The acute toxicity test was carried out according to the organization for economic co-operation and development (OECD) guidelines to establish the effective dose of the test compounds after obtaining ethical clearance from ethics committee of K.S. Hegde Medical Academy, Deralakatte, Mangalore, India (Ethical Clearance Reg. No. KSHEMA/AEC/093/2009).

\section{Acute toxicity}

Adult female albino rats weighing 150-230 g were grouped into six groups of six animals each, starved for $24 \mathrm{~h}$. On the day of the experiment, animals were

Table 3: Antitumor activities of synthesized pyrazolines

\begin{tabular}{lcccc}
\hline Pyrazolines & \multicolumn{4}{c}{$\begin{array}{c}\text { No. of dead cells }(\%) \text { at different } \\
\text { concentrations }(\boldsymbol{\mu g} / \mathbf{m l})\end{array}$} \\
\cline { 2 - 5 } & $\mathbf{5 0}$ & $\mathbf{1 0 0}$ & $\mathbf{2 0 0}$ & $\mathbf{2 5 0}$ \\
\hline Control & & & & \\
IV & 20 & 45 & 68 & 78 \\
IVb & 26 & 28 & 58 & 65 \\
IVd & 16 & 20 & 27 & 43 \\
Va & 10 & 15 & 42 & 55 \\
Vb & 14 & 17 & 22 & 32 \\
5-Fluorouracil & 45 & 80 & 100 & 100 \\
\hline
\end{tabular}

orally administered different compounds to different groups with an increasing dose of 10, 20, 100, 200, 1000, and $2000 \mathrm{mg} / \mathrm{kg}$ body weight. Then, the animals were observed continuously for $3 \mathrm{~h}$ concerning the general behavioral, neurological, and autonomic profiles, then, every $30 \mathrm{~min}$ for the next $3 \mathrm{~h}$, and finally for the next $24 \mathrm{~h}$ or until death.

\section{Analgesic activity}

The analgesic activity of the test compounds was carried out in vivo by the tail immersion method. ${ }^{[13]}$ Pentazocine $(10 \mathrm{mg} / \mathrm{kg})$ was administered as standard for comparison and test compounds at a dose level of $50 \mathrm{mg} / \mathrm{kg}$ were administered orally. The lower portion of the tail was immersed in the thermostatic organ bath in which water is maintained at exactly $55^{\circ} \mathrm{C}$. Within few seconds the rat reacts by withdrawing the tail. The reaction times 0 , $30,60,90$, and $120 \mathrm{~min}$ after the treatment of the test substance were noted. Increased or decreased in reaction time of the test substance was then compared with standard drug treated and solvent treated. The results are given in Table 4.

Percentage increase in reaction time $=\left[\left(R_{t} / R_{c}\right)-1\right) \times 100$, where $R_{t}$ is mean reaction time of the treated group and $R_{c}$ is mean reaction time of control group.

\section{Anti-inflammatory activity}

The anti-inflammatory of the test compounds was carried out using the carrageenan-induced rat paw edema inhibition method according to Winter et al. ${ }^{[14]}$ Acute inflammation was produced by subplantar injection of $0.1 \mathrm{ml}$ of $1 \%$ suspension of carrageenan in the right hind paw of the rats, 30 min after oral administration of the drugs. The paw volume was measured plethysmometrically (IITC digital plethysmograph IITC-520) at 1, 2, 3, and

Table 4: Analgesic activities of synthesized pyrazolines

\begin{tabular}{|c|c|c|c|c|}
\hline \multirow[t]{2}{*}{ Treatment } & \multicolumn{4}{|c|}{ Reaction time in sec at time (min) } \\
\hline & 30 & 60 & 90 & 120 \\
\hline Control & $2.27 \pm 0.03$ & $2.65 \pm 0.02$ & $2.83 \pm 0.03$ & $2.75 \pm 0.04$ \\
\hline Pentazocine & $5.21 \pm 0.04 * *$ & $7.34 \pm 0.02 * *$ & $8.7 \pm 0.10^{* *}$ & $5.38 \pm 0.09 * *$ \\
\hline IV & $4.8 \pm 0.04 * *$ & $6.9 \pm 0.02 * *$ & $8.33 \pm 0.05^{* *}$ & $5.9 \pm 0.03 *$ \\
\hline $\mathrm{IVb}$ & $4.3 \pm 0.04 * *$ & $6.2 \pm 0.05 * *$ & $7.9 \pm 0.03 * *$ & $5.3 \pm 0.05^{* *}$ \\
\hline IVc & $2.38 \pm 0.02$ & $2.99 \pm 0.03 *$ & $3.99 \pm 0.04 *$ & $3.87 \pm 0.02 *$ \\
\hline IVd & $2.22 \pm 0.03$ & $2.9 \pm 0.04 *$ & $3.10 \pm 0.04 *$ & $2.92 \pm 0.04 *$ \\
\hline IVe & $4.5 \pm 0.02 * *$ & $6.8 \pm 0.04 * *$ & $8.0 \pm 0.03 * *$ & $6.8 \pm 0.04 * *$ \\
\hline Va & $4.6 \pm 0.04 * *$ & $6.4 \pm 0.03 * *$ & $7.9 \pm 0.03 * *$ & $5.67 \pm 0.03 * *$ \\
\hline $\mathrm{Vb}$ & $3.75 \pm 0.03 * *$ & $6.03 \pm 0.03 * *$ & $7.77 \pm 0.04 * *$ & $4.9 \pm 0.03 * *$ \\
\hline $\mathrm{Vc}$ & $2.39 \pm 0.02$ & $3.24 \pm 0.03 *$ & $3.95 \pm 0.03 *$ & $3.5 \pm 0.03 *$ \\
\hline $\mathrm{Vd}$ & $4.76 \pm 0.03 * *$ & $6.13 \pm 0.03 * *$ & $8.12 \pm 0.02 * *$ & $5.15 \pm 0.03 * *$ \\
\hline $\mathrm{Ve}$ & $4.29 \pm 0.03 * *$ & $6.45 \pm 0.03 * *$ & $8.2 \pm 0.03$ & $5.58 \pm 0.04 *$ \\
\hline
\end{tabular}
Journal of Young Pharmacists Vol 4 / No 2 
$4 \mathrm{~h}$ after the carrageenan injection. Indomethacin was used as the standard drug at a dose level of $10 \mathrm{mg} / \mathrm{kg}$. The percentage inhibition of edema was calculated using the formula,

$\%$ Inhibition $=\left(1-V_{\mathrm{t}} / V_{\mathrm{c}}\right) \times 100$,

where $V_{\mathrm{t}}$ and $V_{\mathrm{c}}$ is the edema volume in treated and control groups, respectively. The results are summarized in Table 5.

\section{RESULTS AND DISCUSSION}

The sequence of the reactions employed for the development of novel pyrazoline derivatives is outlined in Scheme 1. Chalcones III $(\mathrm{a}-\mathrm{h})$ were synthesized by the condensation of 2-acetyl thiophene I with various substituted benzaldehydes II in the presence of $\mathrm{NaOH}$. This chalcones on cyclization with phenyl hydrazine and hydrazine hydrate gave pyrazolines IV, V (a-e), respectively, in the presence of pyridine as catalyst.

The structures of newly synthesized compounds are well supported by spectral data such as IR, NMR, and Mass spectral analysis. The formation of title compounds IV, $\mathrm{V}$ $(a-e)$ is indicated by the disappearance of peak due to $\mathrm{C}=\mathrm{O}$ of the intermediate chalcones and the presence of peaks due to $\mathrm{C}=\mathrm{N}$ of the pyrazoline ring in IR spectra as given above. Further, in their ${ }^{1} \mathrm{H}$ NMR spectrum, the appearance of a signal at $\delta 3.064-3.124$ (dd, $1 \mathrm{H}, \mathrm{Ha}$ ), 3.786-3.859 (dd, $1 \mathrm{H}, \mathrm{Hb}), 5.213-5.261$ (dd, $1 \mathrm{H}, \mathrm{Hc})$, confirms the presence of the pyrazoline ring.

All the tested compounds showed antitumor effects and are reported. Compounds IVa and IVb showed the highest

Table 5: Anti-inflammatory activities of synthesized pyrazolines

\begin{tabular}{lcccc}
\hline Treatment & \multicolumn{4}{c}{ Mean paw volume at different time intervals } \\
\cline { 2 - 5 } & $\mathbf{1 ~ h}$ & $\mathbf{2 ~ h}$ & $\mathbf{3 ~ h}$ & $\mathbf{4} \mathbf{~ h}$ \\
\hline Control & $0.46 \pm 0.01$ & $0.68 \pm 0.01$ & $0.79 \pm 0.01$ & $0.88 \pm 0.01$ \\
Indomethacin & $0.22 \pm 0.01 * *$ & $0.20 \pm 0.01 * *$ & $0.19 \pm 0.01 * *$ & $0.11 \pm 0.01 * *$ \\
$\mathrm{IV}$ & $0.39 \pm 0.02 * *$ & $0.35 \pm 0.02 * *$ & $0.34 \pm 0.02 * *$ & $0.21 \pm 0.01 * *$ \\
$\mathrm{IVb}$ & $0.45 \pm 0.02 *$ & $0.38 \pm 0.01 *$ & $0.31 \pm 0.03 *$ & $0.29 \pm 0.02 *$ \\
$\mathrm{IVc}$ & $0.23 \pm 0.01 * *$ & $0.21 \pm 0.01 * *$ & $0.20 \pm 0.02 * *$ & $0.18 \pm 0.02 * *$ \\
$\mathrm{IVd}$ & $0.28 \pm 0.01 *$ & $0.25 \pm 0.02 *$ & $0.21 \pm 0.02 *$ & $0.15 \pm 0.01 *$ \\
$\mathrm{IVe}$ & $0.41 \pm 0.01 *$ & $0.37 \pm 0.02 *$ & $0.32 \pm 0.03 *$ & $0.27 \pm 0.02 *$ \\
$\mathrm{Va}$ & $0.35 \pm 0.02 * *$ & $0.30 \pm 0.02 * *$ & $0.28 \pm 0.01 * *$ & $0.19 \pm 0.01 * *$ \\
$\mathrm{Vb}$ & $0.42 \pm 0.01 *$ & $0.39 \pm 0.03 *$ & $0.30 \pm 0.01 *$ & $0.25 \pm 0.01 *$ \\
$\mathrm{Vc}$ & $0.38 \pm 0.01 * *$ & $0.35 \pm 0.02 * *$ & $0.27 \pm 0.02 * *$ & $0.20 \pm 0.02 * *$ \\
$\mathrm{Vd}$ & $0.47 \pm 0.01 *$ & $0.43 \pm 0.02 *$ & $0.38 \pm 0.01 *$ & $0.31 \pm 0.01 *$ \\
$\mathrm{Ve}$ & $0.29 \pm 0.02 * *$ & $0.26 \pm 0.01 * *$ & $0.23 \pm 0.02 * *$ & $0.17 \pm 0.01 * *$ \\
\hline $\mathrm{Valucs}$ & &
\end{tabular}

Values are expressed as mean \pm SEM of six animals in each group. *Statistically significant $(P \leq 0.05)$. ${ }^{* *}$ Statistically significant $(P \leq 0.001)$

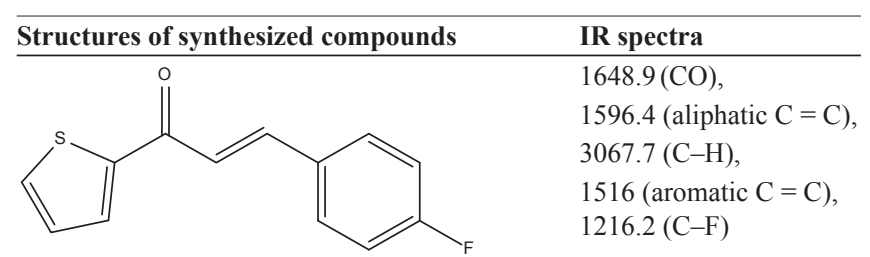

3-(4-fluorophenyl)-1-(thiophen-2-yl) prop-2-en-1-one

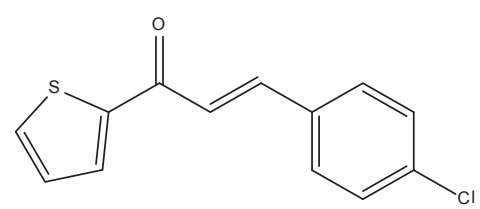

$1672.8(\mathrm{CO})$ group,

1611.3 (aliphatic $\mathrm{C}=\mathrm{C}$ ), 2924.1 (C-H),

1533.7 (aromatic $\mathrm{C}=\mathrm{C}$ ), $765.3(\mathrm{C}-\mathrm{Cl})$

3-(4-chlorophenyl)-1-(thiophen-2-yl) prop-2-en-1-one

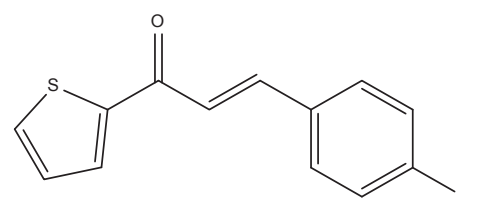

1683.5 (CO),

1609.7 (aliphatic $\mathrm{C}=\mathrm{C}$ ), 2987.3 (C-H),

1523.5 (aromatic $\mathrm{C}=\mathrm{C}$ )

3-(4-methylphenyl)-1-(thiophen-2-yl) prop-2-en-1-one

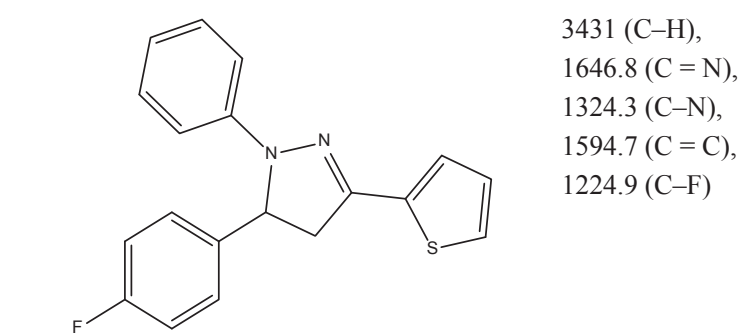

5-(4-fluorophenyl)-1-phenyl-3-(thiophen-2-yl)-4, 5-dihydro-1H-pyrazole

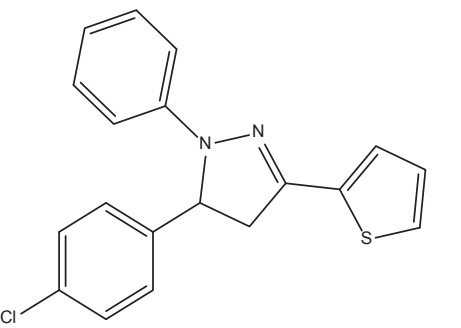

$3039.6(\mathrm{C}-\mathrm{H})$, $1635.6(\mathrm{C}=\mathrm{N})$, $1336.7(\mathrm{C}-\mathrm{N})$, $1522.5(\mathrm{C}=\mathrm{C})$, $703.8(\mathrm{C}-\mathrm{Cl})$.

5-(4-chlorophenyl)-1-phenyl-3-(thiophen-2-yl)-4, 5-dihydro-1H-pyrazole<smiles>Clc1ccc(C2CC(c3cccs3)=NN2)cc1</smiles>

$3239.2(\mathrm{C}-\mathrm{H})$, $1546.3(\mathrm{C}=\mathrm{N})$, $1499.33(\mathrm{C}-\mathrm{N})$, $1523.9(\mathrm{C}=\mathrm{C})$, $1197.3(\mathrm{C}-\mathrm{F})$.

5-(4-chlorophenyl)-3-(thiophen-2-yl)-4, 5-dihydro-1 H-pyrazole<smiles>Fc1ccc(C2CC(c3cccs3)=NN2)cc1</smiles>

$3141.1(\mathrm{C}-\mathrm{H})$, $1689.6(\mathrm{C}=\mathrm{N})$, $1421.3(\mathrm{C}-\mathrm{N})$, $1583.9(\mathrm{C}=\mathrm{C})$, $737.2(\mathrm{C}-\mathrm{Cl})$ 


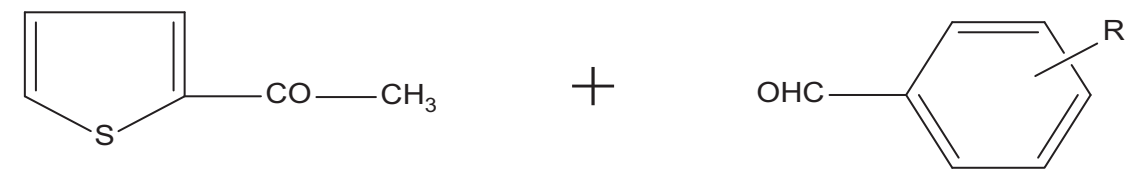

I
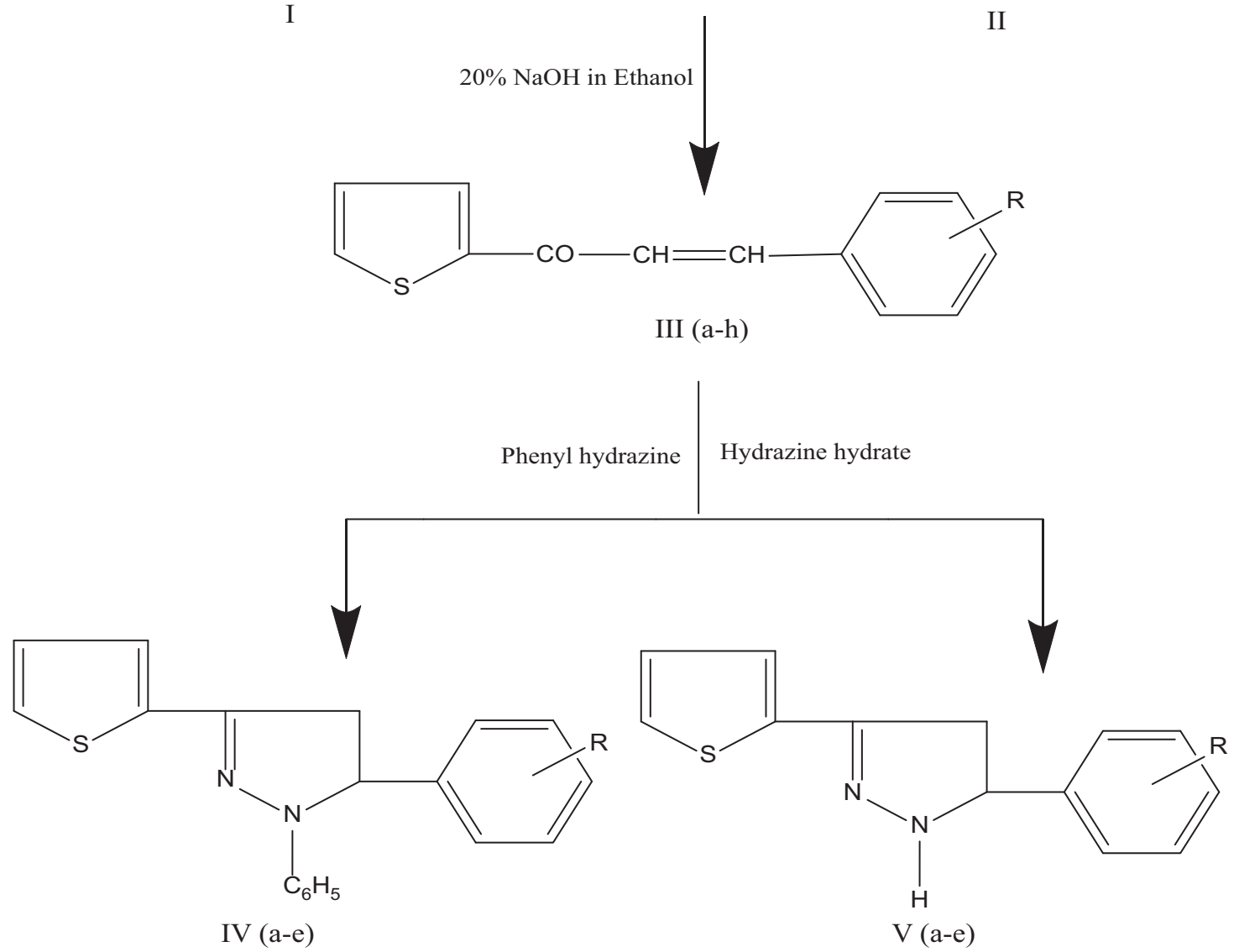

Scheme 1: Synthesis of pyrazolines from the intermediate chalcones. I, 2-Acetyl thiophene; II, substituted benzaldehydes; III, substituted chalcones; IV and V, aubstituted pyrazolines. $\mathrm{R}=\mathrm{Cl}, \mathrm{F}, \mathrm{CH}_{3}, \mathrm{OH}, \mathrm{NO}_{2}$.

Compounds IVc, IVd, and Ve are found to be the most effective anti-inflammatory agents. The results indicate the percentage inhibition of inflammatory.

\section{CONCLUSION}

Thus the results show that synthesized compounds possess antitumor, analgesic, and anti-inflammatory activities. Their synthesis was simple with satisfactory yields. It was observed that the test compounds with electron withdrawing groups (halogens) on the aromatic ring favors antitumor, analgesic, and anti-inflammatory activities. However, further studies are required to establish the exact mechanism of action.

\section{REFERENCES}

1. Gogte VN, Shah LG, Tilak BD, Gadekar KN, Sahasrabudhe MB. Synthesis of potential anticancer agents-Synthesis of substituted thiophene.
Tetrahedron 1967;23:2437-41.

2. Johnson M, Younglove B, Lee L, LeBlanc R, Holt H Jr, Hills P, et al. Design, synthesis, and biological testing of pyrazoline derivatives of combretastatin-A4. Bioorg Med Chem Lett 2007;17:5897-901.

3. Shaharyar M, Ali MA, Siddiqui AA. Synthesis, structural activity relationship and anti-tubercular activity of novel pyrazoline derivatives. Eur J Med Chem 2007;42:268-75.

4. Ozdemir Z, Kandilci HB, Gümüşel B, Caliş U, Bilgin AA. Synthesis and studies on antidepressant and anticonvulsant activities of some 3-(2-furyl)-pyrazoline derivatives. Eur J Med Chem 2007;42:373-9.

5. Yar MS, Siddiqui AA, Ali MA, Murugan V, Chandrashekhar R. Synthesis and cytotoxic activity of novel pyrazoline derivatives against human lung tumor cell line (A549). J Chin Chem Soc 2007;54:81-6.

6. Joshi RS, Mandhane PG, Diwakar SD, Dabhade SK, Gill CH. Synthesis, analgesic and anti-inflammatory activities of some novel pyrazolines derivatives. Bioorg Med Chem Lett 2010;20:3721-5.

7. Shaharyar M, Abdullah MM, Bakht MA, Majeed J. Pyrazoline bearing benzimidazoles: Search for anticancer agents. Eur J Med Chem 2010;45:114-9.

8. Li R, Kenyon GL, Cohen FE, Chen X, Gong B, Dominguez JN, et al. In vitro antimalarial activity of chalcones and their derivatives. J Med Chem 1995;38:5031-7.

9. Anto RJ, Sukumaran K, Kuttan G, Rao MN, Subbaraju V, Kuttan R. Anticancer and antioxidant activity of synthetic chalcones and related compounds. Cancer Lett 1995;97:33-7. 
10. Oyedapo OA, Adewunmi CO, Iwalewa EO, Makanju VO. Analgesic, antioxidant and anti-inflammatory related activities of 21-hydroxy-2,41-dimethoxychalcone and 4-hydroxychalcone in mice. J Biol Sci 2008;8:131-6.

11. Sugiura K. Effect of various compounds on the Ehrlich ascites carcinoma. Cancer Res 1953;13:431-41.

12. Kuttan R, Bhanumathy P, Nirmala K, George MC. Potential anticancer activity of turmeric (Curcuma longa). Cancer Lett 1985; 29:197-202.

13. Sewell RD, Spencer PS. Antinociceptive activity of narcotic agonist and partial agonist analgesics and other agents in the tail-immersion test in mice and rats. Neuropharmacology 1976;15:683-8.

14. Winter CA, Risley EA, Nuss GW. Carrageenin-induced edema in hind paws of the rat as an assay for antiiflammatory drugs. Proc Soc Exp Biol Med 1962; 111:544-7.

How to cite this article: Jainey PJ, Bhat IK. Antitumor, analgesic, and antiinflammatory activities of synthesized pyrazolines. J Young Pharmacists $2012 ; 4: 82-7$

Source of Support: Nil, Conflict of Interest: None declared.

\section{Author Help: Online submission of the manuscripts}

Articles can be submitted online from http://www.journalonweb.com. For online submission, the articles should be prepared in two files (first page file and article file). Images should be submitted separately.

\section{1) First Page File:}

Prepare the title page, covering letter, acknowledgement etc. using a word processor program. All information related to your identity should be included here. Use text/rtt/doc/pdf files. Do not zip the files.

\section{2) Article File:}

The main text of the article, beginning with the Abstract to References (including tables) should be in this file. Do not include any information (such as acknowledgement, your names in page headers etc.) in this file. Use text/rtf/doc/pdf files. Do not zip the files. Limit the file size to $1 \mathrm{MB}$. Do not incorporate images in the file. If file size is large, graphs can be submitted separately as images, without their being incorporated in the article file. This will reduce the size of the file.

3) Images:

Submit good quality color images. Each image should be less than 4 MB in size. The size of the image can be reduced by decreasing the actual height and width of the images (keep up to about 6 inches and up to about $1800 \times 1200$ pixels). JPEG is the most suitable file format. The image quality should be good enough to judge the scientific value of the image. For the purpose of printing, always retain a good quality, high resolution image. This high resolution image should be sent to the editorial office at the time of sending a revised article.

4) Legends:

Legends for the figures/images should be included at the end of the article file. 